УДК 355:371.3(378)

Мітягін О. О., канд. іст. наук

(0000-0002-2230-5150);

Вітер Д. В., д-р філос. наук, ст. наук. співроб.

(0000-0002-7330-1280)

Центр воєнно-стратегічних досліджень Національного університету оборони України імені Івана Черняховського, Київ

\title{
Стратегічні пріоритети підвищення боєздатності Збройних Сил України в контексті професіоналізації військової освіти: політики і процедури
}

Резюме. У статті розглянуто питання визначення та реалізації стратегічних пріоритетів підвищення боєздатності Збройних Сил України в контексті професіоналізації військової освіти.

Ключові слова: боєздатність; військова політика; збройні сили; концепція; професійна військова освіта; процедури; стратегічні пріоритети.

Постановка проблеми. Інтереси національної безпеки і оборони, які зв'язані із запобіганням виникненню та розвитку збройних конфліктів на території держави, із забезпеченням іiі здатності протистояти зовнішній агресії, потребують від Збройних Сил України постійно підтримувати та розширювати свої можливості, протидіяти наявним і потенційним загрозам і небезпекам, ураховувати зміни, які відбуваються у збройних силах противника, завчасно й адекватно реагувати на зміни форм і способів ведення збройної боротьби, іiі характеру, основних принципів, урахування загальних змін у безпековому, стратегічному i операційному середовищі.

Ефективне розв'язання проблем, зв'язаних із забезпеченням інтересів національної безпеки i оборони, не обмежується виключно застосуванням збройних сил (далі - 3С) держави, які є лише одним 3 елементів системи забезпечення національної безпеки і оборони та мають співпрацювати, проводити спільні операції і заходи 3 іншими складовими сил безпеки i оборони. Це потребує розширення можливостей сумісності не тільки на рівні видів і родів ЗС, але й на рівні міжвідомчої взаємодії та координації. Водночас мають бути створені умови для забезпечення сумісності видів і родів ЗС 3 підрозділами інших складових сил безпеки і оборони на всіх рівнях, що має на меті отримання якісної переваги, як основи успішного застосування військової сили, на підгрунті професіоналізації військової освіти, сучасний стан якої характеризується інституційною розгалуженістю, традиційною орієнтацією на фундаментальну підготовку. Проте нагальною виявляється потреба розвитку професійної складової військової освіти, зміна структури професійної підготовки офіцерів у безпосередньому зв'язку 3 розв'язанням питань узгодженості процесів отримання вищої військової освіти, професійного та кар'єрного зростання офіцера, що на сьогодні $\epsilon$ одним 3 важливих пріоритетів підвищення боєздатності військ (сил).

Аналіз останніх досліджень i публікацій. Дослідженню питань розвитку вищої військової освіти в Україні приділили увагу такі вітчизняні вчені, як А. Долматов, А. Зельницький, М. Нещадим, В. Ягупов, які розвинули у своїх роботах системний, комплексний, компетентнісний підходи, підхід до оцінювання якості військової освіти, загальні напрями iï професіоналізації тощо. Зарубіжні науковці, зокрема А. Ваггенер, Дж. Джонсон-Фріз, К. Келлі, Е. Фрейдсон, М. Херш $[3-5,8]$, окрему увагу звертають на необхідність приведення у відповідність системи вищої військової освіти, професійної військової освіти та загальної стратегії розвитку ЗС. Проте потребує дослідження питання визначення політик i процедур стратегії розвитку професійної військової освіти.

Метою статі $\epsilon$ визначення політик i процедур щодо забезпечення стратегічних пріоритетів підвищення боєздатності ЗС України в контексті професіоналізації військової освіти.

Виклад основного матеріалу. Головна мета професійної військової освіти полягає у наданні майбутньому офіцеру знань, умінь $\mathrm{i}$ навичок, які забезпечать своєчасне прийняття вірного рішення в складних умовах обстановки. Це стосується як воєнного, так і мирного часу, адже ЗС мають постійно зберігати високий рівень боєготовності та боєздатності, що актуалізує необхідність професійної підготовки офіцерів до вирішення завдань будь-якої складності завчасно. Офіцер має бути постійно готовим до виконання 
завдань, а рівень його освіти і професійної підготовки має відповідати реальним потребам ЗС та можливостям самого офіцера, отримуючи інтегративний характер та визначаючи зміст i напрями його професійного розвитку.

Переважна більшість сучасних досліджень акцентує увагу на інтегративному характері професійного розвитку, який передбачає інтеграцію органів управління військовою освітою, мережі закладів військової освіти, діючих стандартів освітньої діяльності та стандартів освіти (професійний стандарт), рівнів і ступенів кваліфікації освіти (галузева рамка кваліфікацій), законодавчої та нормативно-правової бази тощо у єдиний комплекс професійної військової освіти та підготовки офіцерів і військових фахівців $[1,4,5,7]$. Відповідно, професіоналізація військової освіти здійснюється на основі вдосконалення процесу професійної підготовки військових фахівців і залишається невід'ємною складовою системи військової освіти України, яка потребує суттєвого вдосконалення ii характеру та змісту 3 урахуванням впливу факторів стратегічного i операційного середовища, стратегічного курсу України на євроатлантичну інтеграцію, участі держави у збройних конфліктах на власній території та поза іiі межами.

3 огляду на досвід країн-членів НАТО, осмислення питань розвитку професійної військової освіти має відображатись у певній стратегії, яка систематизує сучасні погляди, принципи i підходи до ефективного функціонування системи військової освіти та якість професійної підготовки офіцерів i військових фахівців у стратегічній перспективі $[2,4,5]$. Це $\epsilon$ важливим завданням, адже існує низка стратегічно важливих проблем, нерозв'язання яких негативно впливає на боєготовність та боєздатність ЗС. Серед таких, 3 погляду розроблення та імплементації стратегії професійної військової освіти (ПВО), найбільш важливими виявляються: постійний відтік офіцерських кадрів із лав ЗС України, внаслідок чого виникає неукомплектованість як первинних офіцерських посад, так і посад в органах військового управління; недосконалість (неадекватність) вибору змісту освіти та навчання за сучасної обстановки 3 урахуванням тенденцій розвитку безпекового, стратегічного і операційного середовища у майбутньому; наявність перешкод, відсутність оптимальної міжвідомчої взаємодії та координації у сфері підготовки офіцерів для проведення спільних операцій; відсутність законодавчого i нормативно-правового закріплення стандартів професійної військової освіти; недостатній рівень теоретичних знань і практичних навичок офіцерів; низький рівень забезпечення кар'єрного зростання офіцерів тощо.

Виникнення цих проблем обумовлене незавершеністю процесу законодавчого та нормативно-правового забезпечення процесу реформування 3С і системі військової освіти (СВО) в Україні, зокрема, галузевої рамки кваліфікацій, професійного стандарту, політики забезпечення і гарантування якості освіти та професійної підготовки офіцерів. В аспекті діючої структури СВО та підготовки військових фахівців варто акцентувати увагу на часткову невідповідність існуючої мережі професійної (курсової) підготовки та підвищення кваліфікації офіцерів, а також організаційно-штатних структур складових перспективам і динаміці розвитку ЗС України. Унаслідок цього актуалізується питання вдосконалення підходів щодо інституційної імплементації нормативно введених військових i цивільних галузей знань та спеціальностей під час планування підготовки військових фахівців, адаптації сучасного досвіду бойової та оперативної підготовки військ (сил), їх застосування у війнах, локальних конфліктах, антитерористичних операціях тощо до навчальних програм, наближення до діючих стандартів і процедур НАТО у сфері професійної військової освіти для забезпечення досягнення необхідного рівня сумісності зі збройними силами країнчленів альянсу.

Важливим також виявляється комплекс зв'язаних з професійною військовою освітою проблем, які стосуються кадрового забезпечення ЗС та проходження офіцерами служби. Зокрема, наявною $є$ неефективність системи кадрового забезпечення ЗС, умов кар'єрного зростання та проходження служби офіцерами на посадах усіх рівнів, що підсилюється відсутністю цілісної, дієвої системи соціально-економічних стимулів за результатами службової діяльності військовослужбовців у військах (силах) тощо. Фактично йдеться про те, що військова освіта має на меті сформувати в офіцера здатність, бажання та вміння вчитись постійно, безперервно. Реалізація цього прагнення здійснюється, зокрема, в системі ПВО, зважаючи на сукупність всіх факторів (інституційні, ситуативні, особистісні тощо), які впливають на особливості проходження 
військової служби (кар'єри), та грунтується на аналізі варіантів щодо оптимізації професійної підготовки офіцерського складу 3 урахуванням формування кадрового потенціалу ЗС України та просування по службі (кар'єрного зростання).

В основу вибору оптимального варіанта професіоналізації військової освіти доцільно покласти принцип поєднання двох основних складових $[7,8]$ :

освітньої - фундаментальна військова освіта 3 підготовки осіб на посади офіцерського складу на певному рівні вищої освіти 3 присудженням їм відповідного ступеня вищої освіти і видачею після успішного завершення навчання диплома державного зразка;

професійної - курсова підготовка офіцерів та військових фахівців, що проводиться у процесі виконання ними службових функцій на посадах у військах (силах) на основі лідерських курсів перед призначенням офіцерів на вищі посади 3 видачею ним після успішного завершення курсів відповідного відомчого сертифікату.

Професійна освіта та професійний розвиток офіцера включає в себе індивідуальне навчання, набуття практичного досвіду, освіту та саморозвиток [1]. Процес навчання та професійної підготовки офіцера $\epsilon$ безперервним i таким, що здійснюється протягом всієї кар'єри, яка безпосередньо залежить від здатності офіцера підтримувати належний рівень професійних знань, його прагнення постійно підвищувати цей рівень. Відтак, роль ПВО полягає у наданні освіти, необхідної для доповнення індивідуального навчання, досвіду виконання службових обов'язків і завдань за призначенням, саморозвитку для набуття офіцером всієї сукупності компетенцій та лідерських якостей. Індивідуальне навчання і розвиток на кожному етапі кар'єрного зростання офіцера, прийняття ним більшої відповідальності й набуття нового досвіду мають у системі ПВО постійно розширюватись та вдосконалюватись, формуючи необхідний тип мислення на кожному професійному рівні.

Підвищення рівня готовності та здатності офіцерів виконувати завдання в умовах проведення спільних операцій, а також виконання функціональних обов'язків у системі спільних штабів потребує початкової орієнтації на воєнно-професійне навчання під час підготовки офіцерів відповідно до рівня їх застосування. Окрема увага має приділятись розширенню можливостей сумісності офіцера під час виконання завдань у межах спільного безпекового i операційного середовища на початкових рівнях отримання військової освіти та професійної підготовки шляхом набуття знань, які закріплюються протягом усього періоду навчання. Це, зокрема, змінює підхід до визначення особливого статусу професії військового, який передбачає баланс спеціальних вимог до підготовки, професійної діяльності та професійного вдосконалення офіцерів i визначених законом гарантій, привілеїв та можливостей за професійною ознакою $[3,6]$. Засади підготовки та професійного вдосконалення офіцерів потребують законодавчого врегулювання i мають бути визначені через галузеву систему кваліфікацій, що потребує регулювання діяльності ВВНЗ та системи професійної (курсової) підготовки в частині формування змісту освіти та організації освітнього процесу, а також додаткові вимоги до систем внутрішнього та зовнішнього забезпечення якості військової освіти щодо змісту, кадрового, матеріально-технічного забезпечення тощо. Формування нового бачення перспектив професії військового, привабливості професійної кар'єри офіцера, престижності здобуття військової освіти в Україні потребує запровадження стратегічної програми державної підтримки здобуття військової освіти.

Водночас система внутрішнього забезпечення якості професійної підготовки офіцерів може додатково передбачати: оцінювання здібностей до виконання завдань; вимоги до викладачів, які здійснюють психолого-педагогічну та методичну підготовку здобувачів військової освіти у ВВНЗ та в системі професійної (курсової) підготовки офіцерів; залучення досвідчених офіцерів відповідних рівнів до викладання окремих курсів чи проведення занять; поєднання навчання зі стажуванням тощо. Додаткові вимоги до системи внутрішнього забезпечення якості підготовки офіцерів встановлюються відповідними стандартами. Зі свого боку система зовнішнього забезпечення якості професійної підготовки офіцерів має передбачати можливість залучення окремих досвідчених офіцерів відповідних рівнів до процедур акредитації освітніх програм та інституційної акредитації (інституційного аудиту) ВВНЗ.

Одним 3 визначних шляхів реалізації стратегічних пріоритетів підвищення боєздатності ЗС у контексті реформи військової освіти, який визначає напрям 
розвитку політик і процедур, $\epsilon$ інститутилізація професійної військової освіти. У цьому випадку йдеться про те, що програми другого (магістерського) та першого (бакалаврського) рівня, які можуть реалізовуватись у ВВНЗ та ВНП ЗВО. Заклади післядипломної військової освіти можуть брати участь у реалізації таких освітніх програм за наявності відповідної ліцензії, зокрема, у разі інтеграції до структури університетів. Регулювання конкурсу 3 військових спеціальностей має здійснюватися на основі визначення потреб у підготовці фахівців відповідного профілю. Програми професійної військової підготовки (курсової підготовки, курси лідерства) реалізуються у спеціалізованих підрозділах ВВН3 і в Національному університеті оборони України імені Івана Черняховського. Реалізація програм професійної військової підготовки (курсової підготовки, курси лідерства) може здійснюватися у співпраці 3 відповідними ВВНЗ та інституціями країн-партнерів та країн-членів НАТО. Однак отримання вищої освіти за освітнім ступенем "магістр" на стратегічному рівні та професійна (курсова) підготовка офіцерів на вищих рівнях (L3, L4) незалежно від їх відомчої приналежності має здійснюватись у Національному університеті оборони України імені Івана Черняховського.

Висновки. Визначення цілей, політик i процедур, що стосуються питання професіоналізації військової освіти на стратегічному рівні має здійснюватись для забезпечення принципу спільного застосування підрозділів 3С, урахування розширення спільного операційного середовища на всіх рівнях ведення збройної боротьби та забезпечення сумісності в умовах розширення співпраці у сфері безпеки i оборони на сучасних ТВД. 3 огляду на це, політики і процедури мають визначати, що виконання офіцерами службових обов'язків у складі спільних, міжвідомчих, міжурядових, багатонаціональних бойових підрозділах, організаціях, штабах потребує наявності відповідних здібностей і можливостей, знань, навичок i вмінь, які формуються та набуваються офіцерами в системі ПВО. Це, зі свого боку, обумовлює необхідність поєднання формальної, фундаментальної освіти з професійним розвитком.

Конкретизація політики у цьому контексті передбачає застосування проблемно-орієнтованого підходу до аналізу структурно-функціональної складової загального процесу кадрового забезпечення
3С, що спрямовано на урахування змін в стратегічному i операційному середовищі, загальних тенденцій розвитку системи національної та міжнародної безпеки, змін форм і способів ведення збройної боротьби.

Процедури стратегії професіоналізації військової освіти у цьому випадку передбачають визначення та поєднання сучасних вимог до якості професійної підготовки офіцерів у контексті динаміки розвитку СВО, професійної підготовки та індивідуального навчання офіцерів ЗС України 3 основним акцентом на визначенні та обгрунтуванні конкретних освітніх рівнів і рівнів курсової підготовки. Це передбачає застосування індивідуальнозорієнтованого підходу, що забезпечує прогресивний характер системи ПВО, у якій основний акцент робиться на індивідуальному розвитку офіцера протягом всього строку служби у військах, його кар'єрного зростання, а також встановлення відповідності кожного рівня професійної підготовки рівням ведення війни (бойових дій).

Перспективи подальших наукових досліджень зв'язані 3 концептуалізацією основних стратегічних пріоритетів підвищення боєздатності 3C шляхом професіоналізації військової освіти, обгрунтуванням зв'язку освітніх рівнів (бакалавр, магістр) та рівнів курсової професійної підготовки зі сферами (функціоналами) та цілями спільного навчання (в рамках проєктів спільного навчання у закладах військової освіти відповідних рівнів країн-членів НАТО та країн-партнерів) у напрямі забезпечення підготовки офіцерів до успішної участі у спільних операціях. Важливим $є$ питання розроблення та імплементації рішень щодо стратегічних пріоритетів підвищення боєздатності ЗС у стратегічній перспективі (період 10-15 років), що має забезпечити СВО та ПВО динамічність і гнучкість, своєчасність реагування на зміни, які відбуваються в безпековому, стратегічному i операційному середовищі.

\section{СПИСОК ВИКОРИСТАНОЇ ЛІТЕРАТУРИ}

1. Augier M., HughesW. Innovative Thinking: The Role of Professional Military Education. URL: http://cimsec.org/innovative-thinking-the-role-ofprofessional-military-education/40280.

2. Freidson E. Professionalism: The Third Logic. Chicago : University of Chicago Press, 2001.

3. Hersh M. Professional Ethics and Social Responsibility: Military Work and Peacebuilding. 
IFAC-PapersOnLine. July 2017. Vol. 50. № 1. p. $10592-10602$.

4. Johnson-Freese J. The Reform of Military Education: Twenty-Five Years Laterse // Orbis. A Journal of World Affairs. 2012. Vol. 56. № 1. p. $135-153$.

5. Kelley K., Johnson-Freese J. Getting to the Goal in Professional Military Education. Orbis. A Journal of World Affairs. Winter 2014. Vol. 58. № 1. p. 119-132.
6. Kohn R. First Priorities in Military Professionalism // Orbis. A Journal of World Affairs. Summer 2013. Vol. 57. № 3. p. 380-389.

7. Professional Military Education. A Cross-Cultural Survey : Ed. by Duraid Jalili and Hubert Annen. Berlin, Bern, Bruxelles, New York, Oxford, Warszawa, Wien, 2019. 234 p.

8. Waggener A. Joint Professional Military Education. A Retrospective of the Skelton Panel // JFQ 77, 2nd Quarter 2015. p. 55-59.

Стаття надійшла до редакційної колегії 08.01.2020

\section{Strategic priorities for rising of Armed Forces of Ukraine combat readiness in the context of military education professionalization: politic and procedure}

\section{Annotation}

Today it is necessary to create a condition for ensuring compatibility of the types and classes of the Armed Forces with the units of other components of the security and defense forces at all levels, with the aim of obtaining a qualitative advantage as a basis for the successful use of military force. This task can be accomplished on the basis of the professionalization of military education, the present state of which is characterized by institutional ramifications, a traditional focus on fundamental training.

Therefore, the need for the development of a professional component of military education, a change in the structure of professional training of officers in direct connection with the solution of the issues of coordination of higher military education, professional and career advancement of the officer, which is one of the important priorities of increasing combat capability troops (forces).

Specification of the policy in this context implies the application of a problem-oriented approach to the analysis of the structural and functional component of the overall process of personnel security of the Armed Forces, aimed at taking into account changes in the strategic and operational environment, the general tendencies of the development of the national and international security system, changes in the forms and methods of conducting the armed struggle.

Procedures for the strategy of professionalization of military education in this case provide for the definition and combination of modern requirements for the quality of professional training of officers in the context of the dynamics of the development of the System of military education, professional and individual training of officers of the Armed Forces of Ukraine, with the main emphasis on the definition and justification of specific educational levels and levels of course training.

This involves applying a person-centered approach that ensures the progressive nature of the system of professional military education, which focuses on the individual development of the officer throughout his life in the military, his career development, as well as establishing the correspondence of each level of training to the levels of warfare (fighting).

Keywords: Armed Forces, combat readiness, conception, military politic, procedure, professional military education, strategic priorities. 